\title{
Sinkretisme Agama dan Budaya dalam Tradisi Sesajen di Desa Prenduan
}

\author{
Aminulah \\ Ula4my@gmail.com \\ Institut Dirosat Islamiyah Al-Amien Prenduan Sumenep
}

\begin{abstract}
Abstrak Sudah menjadi kenyataan klasik, bahwa kebudayaan tidak bisa dipisahkan dari kehidupan manusia yang menganut agamanya masing-masing. Bagi kita umat Islam, tidak semua budaya sejalan dengan ajaran agama. Salah satunya adalah tradisi sesajen yang dianggap syirik oleh sebagian tokoh Islam. Namun pada kenyataannya, tradisi ini masih dilakukan oleh masyarakat Desa Prenduan yang mayoritas beragama Islam. Hal ini menggambarkan bahwa terdapat sinkretisme antara agama dan budaya dalam tradisi sesajen tersebut. Penelitian ini difokuskan pasa proses sinkretisasi dan nilai sinkretis dari sesajen tersebut. Dalam hal ini, peneliti menggunakan pendekatan kualitatif dengan jenis fenomenologi. Kata-kata, tindakan serta data tertulis dlapangan akan dikumpulkan dengan menggunakan wawancara, observasi dan dokumentasi yang semuanya dimasukan dalam catatan lapangan. Kemudian dilakukan analisis data tentang sesajen ini melalui reduksi, kategorisasi,
\end{abstract}


2-16 | Aminulah

sintesisasi dan penyusunan hipotesis kerja terkait fukus penelitian. Dari hasil penelitian dapat disimpulkan bahwa proses sinkretisasi di Desa Prenduan diawali dari tradisi sesajen yang tidak bisa dihilangkan serta penurunan pemahaman masyarakat Prenduan sendiri tentang sesajen tersebut. Oleh karena itu para ulama berusaha mengisi ketidak tahuan itu dengan memasukan ajaran Islam ke dalam keyakinan dan tata cara sesajen tersebut. Sehingga dapat dikatakan bahwa nilai sinkretis dalam tradisi tersebut terletak pada tata cara dan bentuk keyakinan masyarakat Prenduan terhadap sesajen tersebut.

Kata kunci: Agama, Budaya, Sinkretisasi dan Sesajen

Abstract It is an obvious fact that culture and religion are often inseparable. For Muslims, some of cultures they live in are sometime not in line with their religion teachings. One of the examples is offering tradition. It is considered shirk for some of Islamic leaders. But then, it is still maintained by people in Prenduan, where the majority is Islamic believers. This shows that this tradition is a syncretic practice combining religious and culture. This research is aimed to investigate the syncretic process and value of offering tradition. Phenomenological approach is used in this study. Data are collected used interview, observation, and documentation which combined in the field notes and analyzed through data reduction, categorizing and making sense of the essential meanings of the phenomenon. The result shows that syncretic process in Prenduan was started from the old offeringtradition which was difficult to stop and the decrease of Prenduan people understanding of the tradition. So that, the Islamic leaders tried to modify the tradition, taking advantage of the limited understanding, by bringing Islamic teachings in people belief and their way of doing offering tradition. This study concludes that syncretic value of the tradition is in the way of doing and the belief of Prenduan people about the tradition.

Keywords: Religion, Culture, Syncretism and Offering 


\section{Pendahuluan}

Agama tidak akan tersebar tanpa budaya, begitu pula sebaliknya budaya akan tersesat tanpa agama. ${ }^{1}$ Dari ungkapan tadi dapat dikatakan bahwa diantara keduanya sebenarnya tidak dapat dipisahkan. Dikarenakan agama yang salah satu tujuan diturunkannya adalah sebagai tuntunan bagi kehidupan manusia harus terbuka dengan segala bentuk kehidupan manusia. Intinya, agama sukar dipisahkan dari budaya karena agama tidak akan dianut oleh umatnya tanpa budaya. Meski setiap agama mempunyai suatu pretensi untuk murni dari budaya, namun faktanya, setiap agama selalu tercampuri oleh budaya tertentu. Terlebih lagi bagi orang Indonesia terutama Jawa, kebudayaan sudah menjadi ciri has. Dengan kata lain, tanpa kebudayaan, masyarakat akan hidup tanpa setatus. ${ }^{2}$ Kita bisa mengatakan bahwa mereka yang berpretensi murni dari budaya sebenarnya berpretensi untuk membentuk kebudayaannya sendiri. ${ }^{3}$ Begitu pula sebaliknya, Teologi pasti akan punya pengaruh terhadap budaya serta terhadap pertanyaanpertanyaan yang akan ditimbulkan oleh budaya itu di masa depan. ${ }^{4}$

Bagi kita umat Islam, tidak semua tradisi dan budaya sesuai dengan ajaran Islam. Salah satunya adalah sesajen. Dalam pandangan hukum Islam, terdapat pendapat yang menyatakan bahwa ritual-ritual seperti pemuliaan dalam bentuk pemujaan kuburan, dan benda-benda lainnya adalah perbuatan syirik. Hal ini seperti yang telah termaktub dalam alQur'an Surah al-An'ām ayat 136.

1 Tedi Sutardi, Antropologi. Mengungkap keragaman budaya, (Bandung: PT. Setia Purna Inves, 2007) h. 22

2 Suwardi Endraswara, Etnologi Jawa, (Yogyakarta: CAPS, 2015)h. 156

3 Budi Munawwar \& Rachman, Argumen Islam untuk Pluralisme, (Jakarta:PT. Grasindo, 2009)

h. 6 o

4 Robert J. Schreiter, Rancang Bangun Teologi Lokal, (Jakarta: Gunung Mulia, 20o6) h. 59 
4-16 | Aminulah

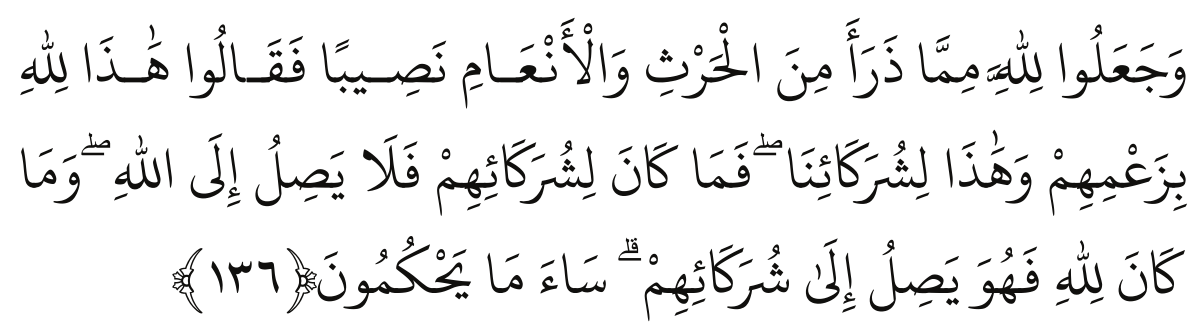

Dan mereka memperuntukkan bagi Allah satu bagian dari tanaman dan ternakyang telah diciptakan Allah, lalu mereka berkata sesuai dengan persangkaan mereka: "Ini untuk Allah dan ini untuk berhalaberhala kami." Maka saji-sajian yang diperuntukkan bagi berhalaberhala mereka tidak sampai kepada Allah; dan saji-sajian yang diperuntukkan bagi Allah, maka sajian itu sampai kepada berhalaberhala mereka. Amat buruklah ketetapan mereka itu.(Q.S: AlAn'ām/6:136)

Praktek memberikan sesajen kepada roh-roh yang merupakan salah satu dari ritual Agama Kejawen ini mendapatkan ejekan dari para pembaru Islam lewat khotbah-khotbahnya. Meskipun begitu, isi khotbah seperti ini mendapat tanggapan pedas dari beberapa minoritas mistisikus Kejawen. Mereka berpendapat bahwa pemikiran yang berorientasi terhadap syariat saja dari kalangan santri adalah syirik sebab perhatiannya lebih besar dan lebih tertuju hanya kepada wadah (ritual) dari pada isi (Allah). ${ }^{5}$

Dari beberapa uraian di atas, dapat ditegaskan bahwa sesajen yang ditujukan kepada yang selain Allah SWT merupakan tradisi sinkretis karena bertentangan dengan ajaran Islam dan tidak sepantasnya dilakukan oleh orang yang beragama Islam. Seperti yang telah kita ketahui bahwa sinkretisme adalah pemikiran yang melecehkan agama. ${ }^{6}$ Karena sinktretisme ditujukan untuk mempersatukan keyakinan yang berbeda dan saling bertentangan tanpa memerdulikan benar salah. ${ }^{7}$

Namun kenyataan, di lapangan mengatakan masih ada masyarakat

5 Mark R. Woodward, Islam Jawa: Kesalehan Normatif Versus Kebatinan, (Yogyakarta: LkiS, 1999) h. 328

${ }^{6}$ Adian Husaini, Penyesatan Opini: Sebuah Rekayasa Mengubah Citra, (Jakarta: Gema InsaniPress, 2002) h. 32 h. 83

7 Emanuel Gerrit Singgih, Berteologi Dengan Konteks, (Yogyakarta: Kanisius, 2000) 
yang mencampuradukkan kebudayaan yang dilarang oleh Islam dengan ajaran Islam itu sendiri. Salah satunya adalah apa yang dilakukan oleh sebagian masyarakat di Desa Prenduan Kecamatan Pragaan Kabupaten Sumenep yang merupakan salah satu wilayah dari Pulau Madura. Dari hasil studi pendahuluan, peneliti menemukan dua ritual kecil yang sinkretis. Kedua ritual itu oleh penduduk desa Prenduan disebut dengan son-sonan dan sontengan. Dalam dua ritual ini terdapat ubo rampe atau perlengkapan sesajen yang ditujukan pada objek yang gaib seperti roh para leluhur, makhluk penjaga tempat-tempat tertentu atau yang lainnya. Jika ditinjau dari segi teori, sesajen di Desa Prenduan termasuk sinkretisasi dalam aspek bentuk ibadat, adat kebiasaan dan praktek keagamaan. ${ }^{8}$ Kegiatan sinkretisme ini dilakukan oleh sebagian besar masyarakat Prenduan yang semuanya adalah beragama Islam. Padahal sejarah mengatakan bahwa keistimewaan orang-orang Parindu[sic] di Madura sendiri dikenal sebagai orang Islam yang sangat saleh. ${ }^{9}$ Sifat keislaman penduduk itu segera nampak. Parindu[sic] mempunyai dua masjid besar, yang dua-duanya pantas untuk suatu kota kecil, lima moshalla dan sejumlah besar langgar. ${ }^{10}$

Kesenjangan antara teori dengan kenyataan ini terjadi dalam tradisi sesajen di Prenduan. kenyataan ini sangat mengherankan bagi kita semua terutama bagi peneliti untuk melakukan penelitian. ${ }^{11}$ Hal ini menjadi latar belakang peneliti untuk memahami tentang proses sinkretisasi antara agama dan budaya dalam tradisi sesajen di Desa Prenduan serta untuk memahami nilai agama dan budaya yang terdapat dalam tradisi sesajen di Desa Prenduan.

\section{Metode Penelitian}

Untuk mengkaji tentang sinkretisme agama dan budaya dalam Tradisi Sesajen di Desa Prenduan ini, peneliti menggunakan pendekatan kualitatif dengan jenis fenomenologi. Artinya peneliti melihat secara objektif

\footnotetext{
${ }^{8}$ Petrus Citra, Antropologi,(Jakarta: PT. Grasindo, 2007 ) h. 41

9 Huub de Jonge, Madura dalam EmpatZaman:Pedagang, Perkembangan Ekonomi dan Islam, (Jakarta: Gramedia,1989) h. 239

${ }^{10}$ Ibid... h. 240

${ }^{11}$ Kebiasaan untuk heran merupakan sesuatu yang penting dalam penelitian. lihat Antonius Simanjuntak, Metode Penelitian Sosial.(Jakarta: Yayasan Pustaka Obor, 2014) h. 75
} 


\section{6-16 | Aminulah}

fenomena yang terkait dengan sesajen di Desa Prenduan. Tahap pertama yang dilakukan peneliti adalah mengumpulkan data yang berhubungan dengan sesajen di Desa Prenduan yang berupa kata-kata dan tindakan serta data tertulis dengan menggunakan metode wawancara, observasi dan dokumentasi. Untuk tehnik pencarian datanya, peneliti menggunakan snowball yang hasilnya dimasukan ke dalam catatan lapangan dengan menggunakan refleksi mengenai analisis. Tahap selanjutnya adalah menganalisis data dengan beberapa tahap. Pertama adalah reduksi data dengan mengambil data yang berhubungan dengan penelitian. Selanjutnya dilakukan kategorisasi dengan pemberian kode pada setiap ide atau tema yang muncul dari data lapangan untuk dijadikan poin-poin jawaban pada setiap fokus penelitian. Kemudian data hasil kategorisasi tersebut dicari keterkaitan antar kategori dengan tahap sintesisasi. Pada tahap terahir akan dilakukan penyusunan hipotesis kerja sebagai kerangka jawaban pada setiap fokus penelitian tentang sinkretisme agama dan budaya dalam tradisi sesajen di Desa Prenduan.

\section{Hasil dan Pembahasan}

\section{Sinkretisasi agama dan budaya dalam tradisi sesajen di Prenduan}

\section{a. Pelestarian sesajen di Desa Prenduan}

Beberapa macam tradisi sesajen sampai sekarang masih dipertahankan oleh sebagian masyarakat Desa Prenduan. Tradisi turun temurun yang menggabungkan dua unsur yaitu agama dan budaya yang terdapat di Desa Prenduan tersebut memang sangat sulit atau bahkan tidak dapat dipisahkan dari kehidupan sebagian masyarakat Desa Prenduan. Hal ini kemungkan besar berdasar pada kenyataan bahwa agama tidak dapat dipisahkan dengan budaya, ${ }^{12}$ tidak terkecuali peleburan unsur agama dan budaya dalam tradisi sesajen di Desa Prenduan.

Selain itu, tujuan masyarakat Prenduan dalam melaksanakan tradisi sesajen ini adalah diantaranya berbakti pada leluhur yang diwujudkan dengan mengirimkan beberapa makanan dan bahan lainnya yang disebut ubo rampe yang diyakini sampai pada para

${ }^{12}$ Tedi Sutardi, Antropologi, h. 22 
Aminulah: Sinkretisme Agama dan Budaya | 7-16

leluhur. Keyakinan ini tidak jauh beda dengan orang Jawa yang pada umumnya berkeyakinan bahwa tidak lama setelah orang meninggal, jiwanya akan berubah menjadi makhluk halus (roh) atau yang disebut dengan lelembut, yang berkeliaran di sekitar tempat tinggalnya. ${ }^{13}$

Berhubungan baik dengan semua makhluk Tuhan juga menjadi tujuan dari pelaksanaan sesajen di Desa Prenduan. Seperti asal mulanya, sesajen hanya dimaksudkan sebagai sedekah kepada kerabat, sanak famili dan semua makhluk Tuhan. Hal ini ditujukan untuk menjaga keselarasan dan keharmunisan antar sesama makhluk Tuhan.

Dapat dikatakan bahwa proses sinkretisasi atau penyesuaian antara aspek agama dan budaya dalam tradisi sesajen di Desa prenduan ini dilatarbelakangi oleh pelestarian tradisi sesajen tersebut yang sampai sekarang masih diyakini sebagai tradisi turun temurun yang harus tetap dilestarikan. Tradisi sesajen oleh sebagian masyarakat diyakini sebagai perantara antara Tuhan dengan manusia. Dapat dikatakan bahwa sesajen bagi sebagian masyarakat Prenduan adalah manifestasi dari syukur atau perlambang suatu permohonan kepada Tuhan yang Maha Esa. ${ }^{14}$

\section{b. Degradasi pemahaman terhadap sesajen}

Pada dasarnya, sejak zaman paleolithikum penghuni kuno Nusantara sudah mengenal berbagai macam ritual pemujan yang salah satunya adalah sesajen. ${ }^{15}$ Namun sebagian besar dari masyarakat Prenduan sendiri tidak mengetahui tentang asal mula dari sesajen yang mereka lakukan. Baik tentang latar belakang dari tradisi sesajen atau tujuan sebenarnya dari pelaksanaan sesajen tersebut. Salah satu sebabnya adalah transfer pewarisan prosesi ritual tidak diikuti dengan penjelasan maksud, tujuan serta simbolsimbol yang tetkandung didalamnya. Dengan demikian orang tua

${ }_{13}$ Mokhamad Sodikin, Sinkretisme Jawa-Islam dalam Serat Wirid Hidayat Jati dan Pengaruhnya Terhadap Ajaran Tasawuf di Jawa Abad Ke-19, (Jurnal Avatara, Vol 1, No 2, Mei 2013),h. 313

${ }^{14}$ Wahyana Giri MC, Sajen dan Ritual Orang Jawa,(Yogyakarta, Narasi, 2010) h. 14

${ }_{15}$ Agus Sunyoto, Atlas Wali Songo, (Depok: Pustaka Iman, 2014) h. 11 


\section{8-16 | Aminulah}

mengenalkan tradisi ritual sebatas kulitnya saja. ${ }^{16}$

Di satu sisi, masyarakat Prenduan dikenal sebagai orang Islam yang sangat saleh. ${ }^{17}$ Pada pertengahan abad yang lalu, di Sumenep terdapat 2.13o ulama Islam, lebih banyak dari pada Madura Barat dan Pamekasan. ${ }^{18}$ Namun di sisi lain masih banyak adat dan kebiasaan yang diindikasikan betentangan atau tidak sesuai dengan ajaran Islam. Sekalipun merupakan pemeluk Islam yang tangguh, banyak juga orang Madura yang tanpa sadar berbuat sesuatu perilaku keagamaan yang tidak disunnahkan Nabi Muhammad Saw. ${ }^{19}$ Salah satunya adalah sampai sekarang masyarakat Prenduan masih percaya bahwa, tapa' dangdang (jejak burung gagak-maksudnya adalah simpang empat) yang dijadikan tempat peletakan perlengkapan sesajen yang dinamakan moang na'as. Dan juga keyakina pada sumur yang dihuni oleh makhluk halus patoghuna (penjaganya) atau se araksa (yang memelihara).

c. Usaha para tokoh agama memasukan nilai Islam ke dalam tradisi sesajen.

Menurunnya pemahaman terhadap sesajen serta ketidak tahuan para pelaksana terhadap keterkaitan antara sesajen dengan hukum Islam menjadi salah satu alasan para tokoh agama untuk memasukkan keyakinan dan tata cara yang sesuai dengan ajaran Islam. Para tokoh agama berusaha memasukka ajaran dan penyegaran keyakinan Islam tampa merusak hubungan baik dengan para pelaksana sesajen. Pemikiran seperti ini sama dengan masyarakat jawa pada umumnya yang lebih menekankan sikap atau etika dalam berbaur dengan seluruh komponen bangsa yang bermacammacam suku dan bahasa, adat dan termasuk agama. Karena manusia Jawa sadar bahwa tak mungkin orang Jawa dapat hidup sendiri. Pandangan demikian senada dengan filsafat Tantularisme khas Jawa yang mengajarkan humanisme dalam segala bidang sinkretisme.

${ }^{16}$ Wahyana Giri MC, Sajen dan Ritual Orang Jawa,(Yogyakarta, Narasi, 2010) h. 13

${ }^{17}$ Huub de Jonge, Madura dalam EmpatZaman:Pedagang, Perkembangan Ekonomi dan Islam, (Jakarta: Gramedia,1989) h. 239

${ }^{18}$ Ibid., h. 241

${ }^{19}$ Ibid h. 48 
Aminulah: Sinkretisme Agama dan Budaya | 9-16

Kenyataan ini mengakibatkan adanya sinkretisme antara agam dan budaya dalam tradisi sesajen di Desa Prenduan. Hal ini dikarenakan para tokoh agama di Prenduan dituntut untuk terbuka terhadap segala bentuk kehidupan masyarakat Prenduan secara keseluruhan. Salah satunya adalah usaha para tokoh agama dalam memasukan ajaran Agama Islam ke dalam keyakinan dan tata cara yang terdapat pada tradisi sesajen yang memang tidak dapat diubah secara keseluruhan dan dalam waktu yang singkat.

\section{Nilai Sinkretis dalam Tradisi Sesajen di Desa Prenduan}

Terdapat tiga macam bentuk sesajen di Desa Prenduan yang bernilai sinkretis. Yaitu sonsonan, sontengan, dan sesajen moang na'as. Tiga bentuk sesajen ini sampai saat ini masih menjadi tradisi yang dilestarikan oleh sebagian masyarakat Prenduan dengan tata cara dan pemahaman yang masuh melekat dalam keyakinan masyarakat Prenduan.

Kenyataan di atas menjadi latar belakang timbulnya beberapa nilai sinkretis dalam sesajen di Desa Prenduan. Di bawah ini akan diuraikan nilai-nilai sinkretis yang terdapat dalam tiga bentuk sesajen yang terdapat di Desa Prenduan tersebut.

a. Menghormati para leluhur dan bersedekah pada tetangga

Para pelaksana sesajen di Prenduan masih berkeyakinan bahwa para leluhur mereka yang sudah meninggal dunia, jiwanya akan menjadi roh yang akan datang pada setiap malam Jum'at. Keyakinan ini tidak jauh beda dengan keyakinan Jawa pada umumnya. Menurut Koentjaraningrat, orang Jawa umumnya berkeyakinan bahwa tidak lama setelah orang meninggal, jiwanya akan berubah menjadi makhluk halus (roh) atau yang disebut dengan lelembut, yang berkeliaran di sekitar tempat tinggalnya. Makhluk halus itu lama-kelamaan akan pergi dari tempat itu, dan saat-saat tertentu keluarganya mengadakan slametan untuk menandai jarak yang telah ditempuh roh menuju alam roh, tempatnya yang abadi kelak, namun roh dapat dihubungi setiap saat bila diperlukan. ${ }^{20}$

${ }^{20}$ Mokhamad Sodikin, Sinkretisme Jawa-Islam dalam Serat Wirid Hidayat Jati dan Pengaruhnya Terhadap Ajaran Tasawuf di Jawa Abad Ke-19, (Jurnal Avatara, Vol 1, No 2, Mei 2013),h. 313 
10-16 | Aminulah

Dengan keyakinan tersebut para pelaksana sesajen di Prenduan tetap melestarikan tradisi tersebut dengan tujuan untuk menghormati para leluhur. Tata cara dengan keyakinan seperti ini tidak dipermasalahkan oleh para tokoh agama di Prenduan. Hal ini dikarenakan dalam ajaran Islam juga dijelaskan bahwa para roh leluhur akan datang di setiap malam untuk melihat rumah dan para anak cucunya yang masih hidup. Serta berharap para anak cucunya tersebut masih mengingat mereka yang sudah meninggal. ${ }^{21}$

Selain menghormati para leluhur, terdapat juga unsur sedekah dalam tradisi sesajen di Desa Prenduan. Sedekah merupakan unsur yang berasal dari ajaran Islam. Unsur sedekah ini diimplementasikan oleh masyarakat Prenduan dengan memberikan beberapa uborampe atau perlengkapan sesajen kepada tetangga sekitar. Dalam Islam sendiri diajarkan bahwa salah satu dari fungsi sedekah adalah pahala yang dapat diniatkan untuk kebaikan orang yang sudah meninggal dunia. Artinya pahala sedekah dari nasi dan lauk yang dibagikan itu akan sampai dan bermamfaat bagi para leluhur kita yang sudah meninggal dunia. ${ }^{22}$

Nilai budaya yang berupa penghormatan terhadap leluhur serta nilai agama yang berupa sedekah terhadap tetangga ini terdapat dalam tradisi sesajen di Desa Prenduan yang berbentuk sonsonan pada setiap malam Jum'at. Dapat dikatan bahwa sinkretisme dalam tradisi sesajen ini adalah pada aspek kepercayaan dan ritual atau tata cara pelaksanaannya.

b. Menghormati makhluk gaib dan bersyukur kepada Allah SWT

Dalambeberapa tradisi sesajenyang dilakukan oleh masyarakat Prenduan, terdapat unsur budaya yang berupa menghormati makhlug gaib. Para pelaksana sesajen di Desa Prenduan berkeyakinan bahwa dengan beberapa alasan, kita sebagai manusia harus menghomati makhluk gaib tersebut dan mewujukan rasa hormat itu dengan meletakkan sesajen. Salah satu alasan itu adalah karena mahkluk

${ }^{21}$ Sayyid Abū Bakr, I'ānat al-Ṭālibìn, j. 2, h. 142

${ }^{22}$ Faisal al-Bu'dani, Buat Apa Shadaqah, (Jakarta, Aula Pustaka, 2008), h. 91 
Aminulah: Sinkretisme Agama dan Budaya | 11-16

gaib tersebut telah menjaga tempat yang dianggap sangat berperan bagi kehidupan masyarakat Prenduan. Dalam penelitian ini tempat yang dimaksudkan adalah sumur. Keyakinan terhadap adanya makhluk penjaga sumur ini sudah dimiliki oleh masyarakat Madura sebagai bagian dari masyarakat Jawa secara keseluruhan. nenek moyang orang Jawa sejak kecil juga memperkenalkan dengan halhal gaib atau makhluk halus penjaga teritorial, seperti penjaga laut, penjaga bumi, penjaga gunung atau semacamnya. ${ }^{23}$

Selain unsur budaya yang berupa penghormatan kepada para makhluk gaib ini, unsur agama juga terdapat dalam tradisi sesajen di Desa Prenduan, yaitu rasa syukur terhadap rejeki Allah SWT yang berupa air. Rasa syukur merupakan salah satu ajaran Islam yang harus diterap dalam kehidupan sehari-hari.

Seperti yang dijelaskan dalam hadits yang diriwayatkan oleh Aḥmad, Abū Dāwūd dan al-Bukhārī sebagai berikut:

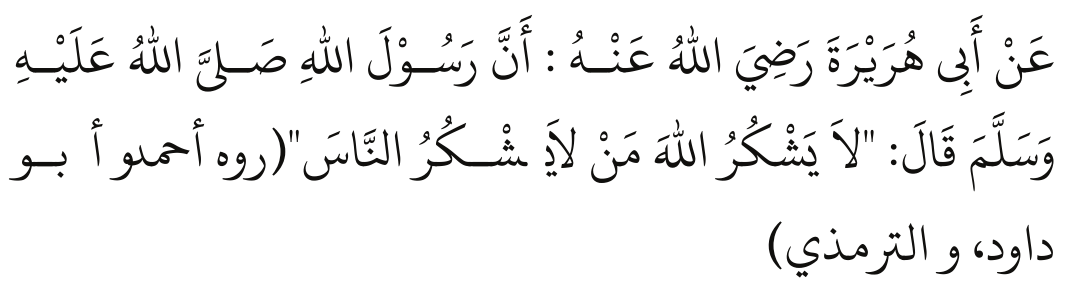

Dari Abū Hurairah r.a., bahwa Nabi Muhammad Saw bersabda, Tidak dianggap bersyukur pada Allah barang siapa yang tidak bersyukur pada manusia. (HR Aḥmad, Abū Dāwud dan alBukhārī)

Dalam teori sebelumnya, dijelaskan bahwa tidak sedikit pula yang menganggap bahwa ubo rampe sajen justru menjadi manifestasi rasa syukur atau perlambang suatu permohonan kepada Tuhan yang Maha Esa. ${ }^{24}$ Rasa syukur ini juga diwujudkan oleh masyarakat Prenduan ke dalam tata cara sesajen di desa tersebut. Beberapa nilai sinkretis yang berupa penghormatan terhadap makhluk gaib dengan nilai syukur kepada Allah ini terdapat dalam tradisi sesajen yang

${ }^{23}$ Wahyana Giri MC, Sajen dan..., h. 15

${ }^{24}$ Ibid., h. 14 
12-16 | Aminulah

berbentuk sontentan dan moang na'as yang masih dilestarikan oleh masyarakat Prenduan.

\section{c. Berhubungan baik dengan semua makhluk Allah}

Berhubungan baik dengan makhluk gaib menjadi salah satu nilai sikretis yang terdapat dalam trasisi sesajen di Desa Prenduan. Masyarakat Prenduan yang mayoritas beragama Islam ini masih mempunyai keyakinan bahwa makhluk gaib itu juga mempunya sifatsifat sebagaimana manusia sepeti iri, dengki, marah, bahagia dan semacamnya. Hal ini dikarenakan masyarakat Desa Prenduan tidak jauh beda dengan masyarakat Jawa pada umumnya. Yaitu memiliki tipologi kehidupan yang selaras. Maka meskipun orang Jawa percaya sepenuhnya kepada Allah yang Maha Esa, namun mereka masih melakukan tegur sapa dengan hal-hal gaib. Hal ini dipertimbangkan demi kehidupan selaras antar sesama makhluk. Agar dalam menjalani permohonan kepada Allah SWT tidak mendapat godaan dan berjalan dengan khusuk. ${ }^{25}$

Nilai budaya yang berupa hubungan baik dengan makhluk gaib tersebut dilatar belakangi oleh nila ajaran Islam. Nilai Islam tersebut adalah masyarakat Prenduan juga meyakini tentang sebagai umat Islam juga mempunyai keharusan untuk berhubungan baik terhadap semua makhluk Allah yang ada di dunia baik yang nyata atau yang giab. Keterangan yang menjelaskan bahwa manusia dapat berhubungan dengan makluk gaib ini dijelaskan dalam salah satu hadits Nabi Saw. 'Umar bin al-Khațtāb pernah bertanya kepada Nabi Muhammad tentang bagaimana Nabi Saw dapat berbicara dengan orang-orang yang sudah meninggal dunia, kemudian jawaban Nabi adalah sebagai berikut:

Demi yang mengutusku dengan kebenaran, mereka lebih mampu mendengar apa yang aku katakan dari pada kalian, hanya saja mereka tidak mampu berbicara ${ }^{26}$

Hadits di atas menjelaskan bahwa manusia tidak hanya

${ }^{25}$ Ibid., h. 15

${ }^{26}$ Ibnu Qayyim Al-Jauziyah, Roh, (Jakarta, Pustaka Al-Kautsar, 2001), h. 15 
Aminulah: Sinkretisme Agama dan Budaya | 13-16 dapat berhubungan dengan sesama manusia namun juga dapat berhubungan dengan makhluk Allah yang gaib. Dalam salah satu ajaran Islam, kita sebagai manusia memang dianjurkan untuk berhubungan baik dengan semua makhluk Allah SWT. ${ }^{27}$ Nilai sinkretis yang berupa hubungan baik dengan sesama makhluk ini terdapat dalam tradisi sesajen di Prenduan yang berbentuk sontengan, sonsonan, dan moang na'as yang sampai sekarang masih dilestarikan oleh masyarakat Prenduan.

Secara keseluruhan, nilai budaya dalam tradisi sesajen di Desa Prenduan masih lebih dominan dari pada nilai agama. Selain dikarenakan nilai budaya yang terlanjur lama melekat, alasan lainnya adalah dikarenakan para tokoh agama tidak mempunyai kesempatan yang baik untuk menjelaskan keyakinan yang benar menurut ajaran Islam, sehingga dihawatirkan keyakinan masyarakat tersebut tertuju pada kesyirikan dengan pemahaman bahwa yang mendatangkan kemudaratan itu adalah mahkluk halus yang diyakini keberadaannya. ${ }^{28}$

\section{Penutup}

Dari hasil penelitin yang diuraikan, sudah dapat dipastikan bahwa terdapat sinkretisme antara agama dan budaya dalam tradisi sesajen di Desa Prenduan. Oleh karena itu, peneliti dapat membagi kesimpulan ini pada dua hal, yaitu proses sinkretisasi dan nilai sinkretis dari tradisi sesajen yang dilakukan oleh sebagian masyarakat Prenduan.

1. Sinkretisasi agama dan budaya dalam tradisi sesajen di Desa Prenduan

Proses sinkretisasi agama dan bUdaya dalam tradisi sesajen di Desa Prenduan ini terjadi dengan beberapa tahap sebagai berikut:

a. Pelestarian tradisi sesajen

Agama dan budaya tidak bisa dilepaskan dari kehidupan masyarakat Prenduan, selain itu, keduanya tidak dapat dipisahkan

${ }^{27}$ Cipta Hening, Di dalam Diri ada Allah, (Elex Media Komputindo,2010) h. XX

${ }^{28}$ Ibrāhīm al-Bajūrī, Al-Tüjān al-Durarì (Kediri, PP. Al-Fatah,tt) h. 6-7 
14-16 | Aminulah

satu sama lain dalam kehidupan sosial mereka secara keseluruhan. Beberapa sudah dilakukan oleh para tokoh agama di Prenduan untuk menghilangkan tradisi tersebut. Namun usaha tersebut tidak dapat menghapus tradisi sesajen secara keseluruhan dari masyarakat Prenduan. Sinkretisme antara agama dan budayapun tidak dapat dihindarkan dari tradisi tersebut. Pelestarian tradisi sesajen di Desa Premduan ini dikarenakan adanya beberapa hal yang melatar belakangi sekaligus tujuan yang masih diyakini oleh sebagian masyarakat Prenduan.

b. Degradasi pemahaman terhadap sesajen

Sebagian besar dari masyarakat Prenduan sendiri tidak mengetahui tentang asal mula dari sesajen yang mereka lakukan. Baik tentang latar belakang dari tradisi sesajen atau tujuan sebenarnya dari pelaksanaan sesajen tersebut. Salah satu sebabnya adalah transfer pewarisan prosesi ritual tidak diikuti dengan penjelasan maksud, tujuan serta simbol-simbol yang tetkandung didalamnya. Dengan demikian orang tua mengenalkan tradisi ritual sebatas kulitnya saja.

c. Usaha tokoh agama dalam memasukan ajaran Islam ke dalam tradisi sesajen

Terlepas dari benar salahnya, peleburan antara keduan unsur tersebut tidak dapat dihindarkan. Dikarenakan hal ini berkaitan dengan upaya masyarakat Prenduan dalam menjaga kehamonisan antara tokoh agama sebagai para penyebar Islam dengan masyarakat pelaksana budaya sebagai objek dari dakwah para tokoh agama di Prenduan. Hal ini berakibat adanya proses sinkretisasi dalam tradisi sesajen di Desa Prenduan.

Secara keseluruhan, sinkretisasi yang terjadi pada tradisi sesajen di Prenduan terjadi karena usaha para tokoh agama untuk menjaga keharmonisan pada masyarakat Prenduan. Para tokoh agama mencoba mencari penyesuaian antara ajaran agama dengan unsur tradisi sesajen tersebut dengan tetap mempertimbangkan nilai keimanan kita yang harus dijaga.

2. Nilai sinkretis yang terdapat dalam tradisi sesajen di Desa Prenduan 
Aminulah: Sinkretisme Agama dan Budaya | 15-16

Terdapat beberapa nilai sinkretis dalam tiga bentuk sesajen di Desa Prenduan. Nilai-nilai tersebut adalah sebagai berikut:

a. Menghormati para leluhur dan bersedekah terhadap tetangga

Menghormati para leluhur adalah unsur budaya dari sesajen yang diwujudkan dengan menyediakan nasi dan lauk yang dinatkan untuk para leluhur yang sudah meninggal. Sedangkan bersedekah adalah unsur ajaran Islam yang diwujudkan dengan membagikan makan tersebut kepada para tetangga dengan niatan bahwa pahala dari sedekah itu akan sampai pada leluhur yang sudah meninggal. Nilai sinkretis ini terdapat dalam tradisi sesajen yang berbentuk sonsonan yang diadakan setiap malam Jum'at.

b. Menghormati makhluk gaib dan bersyukur kepada Allah SWT

Menghirmati para makhluk gaib diwujudkan dengan meletakkan beberapa makanan pada tempat tertentu. Sedangkan rasya syukur merupakan unsur agama dalam tradisi sesajen tersebut. Nilai ini terdapat dalam tradisi sesajen yang berbentuk sontengan.

c. Berhubungan baik dengan semua mahkluk Allah

Melakukan tegur sapa merupakan implementasi dari berhubungan baik dengan sesama makhluk. Sedangkan Islam sendiri mengajarkan manusia untuk berbuat baik dengan semua makhluk Allah SWT.

\section{Daftar Pustaka}

Abū Bakr, al-Sayyid. I'ānat al-Tālibìn, Juz. 2

Al-Bajūrī, Ibrāhīm. Al-Tījān al-Durarī. Kediri: PP. Al-Fatah, tt.

Citra, Petrus. Antropologi. Jakarta: PT. Grasindo, 2007.

De Huub Jonge, Madura Dalam Empat Zaman: Pedagang, Perkembangan

Ekonomi dan Islam, Jakarta: Gramedia, 1989.

Endraswara, Suwardi. EtnologiJawa. Yogyakarta: CAPS, 2015.

Faisal al-Bu'dani, Buat Apa Shadaqah, Jakarta, Aula Pustaka, 2008.

Hening Cipta, Di dalam Diri ada Allah, Elex Media Komputindo,2010. 
16-16 | Aminulah

Husaini, Adian. Penyesatan Opini: Sebuah Rekayasa Mengubah Citra. Jakarta: Gema Insani Press, 2002.

Ibnu Qayyim Al-Jauziyah, Roh, Jakarta, Pustaka Al-Kautsar, 2001

J, Robert Schreiter. Rancang Bangun Teologi Lokal, Jakarta: Gunung Mulia, 2006.

MC. Wahyana Giri, Sajen dan Ritual Orang Jawa, Yogyakarta, Narasi, 2010.

Mokhamad Sodikin, Sinkretisme Jawa-Islam dalam Serat Wirid Hidayat Jati dan Pengaruhnya Terhadap Ajaran Tasawuf di Jawa Abad Ke-19, Jurnal Avatara, Vol 1, No 2, Mei 2013.

Munawwar, Budi \& Rachman. Argumen Islam untuk Pluralisme. Jakarta: Grasindo, 2009.

R Woodward, Mark. Islam Jawa: Kesalehan Normatif Versus Kebatinan, Yogyakarta: Lkis, 1999.

Simanjuntak, Antonius, Metode Penelitian Sosial. Jakarta: Yayasan Pustaka Obor, 2014.

Singgih, Emanuel Gerrit, Berteologi Dengan Konteks, Yogyakarta: Kanisius, 2000.

Sutardi, Tedi. Antropologi:Mengungkap keragaman budaya. Bandung: Setia Purna Inves, 2007. 